\title{
The structure of the female reproductive system of nematodes from the genus Steinernema (Rhabditida: Steinernematidae)
}

\author{
Julia K. ZOGRAF ${ }^{1, *}$, Wim BERT ${ }^{2}$ and Gaetan BORGONIE ${ }^{2}$ \\ ${ }^{1}$ A.V. Zhirmunski Institute of Marine Biology, Far Eastern Branch of Russian Academy of Sciences, \\ Vladivostok, 690041, Russia \\ ${ }^{2}$ Nematology Section, Department of Biology, Ghent University, Ledegankstraat, 35, 9000, Ghent, Belgium
}

Received: 30 January 2008; revised: 31 March 2008 Accepted for publication: 31 March 2008

\begin{abstract}
Summary - Females of six species of nematodes from the genus Steinernema (S. affine, S. arenarium, S. bicornutum, S. carpocapsae, S. feltiae and $S$. glaseri) were studied using light microscopy. Investigation of the gonoduct morphology was completed with ultrastructural data for S. carpocapsae and S. feltiae. Except for S. bicornutum, all species studied show an overall similarity in reproductive system architecture, i.e., a swollen proximal region of the ovaries, an oviduct consisting of irregular rows with two to four cells in cross-section and a uterus divided into two morphologically distinguishable parts (except $S$. carpocapsae). Such a gonoduct structure is distinctive from any other known nematode gonoduct, especially the particular arrangement of the oviduct cells in mostly long irregular rows with two to four cells in cross-section (except S. bicornutum), which is, according to current knowledge, unique within the Rhabditida. These results indicate the coherence of the genus Steinernema as shown from other morphological and molecular studies. The distal swelling of the uterus is considered to be a spermatheca-uterus complex that possibly functions to store and activate sperm and as a fertilisation chamber. The diversity of the cellular architecture of the Steinernema gonoduct provides valuable information for the delineation of species within a morphologically conserved genus. Furthermore, limited results point to a congruence between the gonoduct characters and current molecular phylogenetic hypothesis within Steinernema. Future studies in this direction must ultimately lead to a better understanding of evolutionary processes within the genus.
\end{abstract}

Keywords - entomopathogenic nematode, gonad, morphology, ovary, SEM, Steinernema affine, Steinernema arenarium, Steinernema bicornutum, Steinernema carpocapsae, Steinernema feltiae, Steinernema glaseri, TEM, ultrastructure.

Entomopathogenic nematodes (EPN) in the family Steinernematidae Chitwood \& Chitwood, 1937 are insect parasites capable of infecting a broad range of insect species. They have been used as biological control agents of insect pests in a variety of crops (Gaugler \& Kaya, 1990; Kaya \& Gaugler, 1993; Ansari et al., 2007). The Steinernematidae currently comprises two genera, Steinernema Travassos, 1927 with more than 50 recognised species, and Neosteinernema Nguyen \& Smart, 1994 with but a single species (Hunt, 2007). Nematodes of the genus Steinernema are found in virtually all terrestrial habitats that support vegetation (Spiridonov et al., 2004). Some authors (Gaugler \& Kaya, 1990; Nguyen \& Smart, 1992) have constructed taxonomic keys based on males and infective juveniles. Identification based solely on infective juveniles may not be accurate as there are few differentiating morpholo- gical characteristics between species and the morphometric ranges of several species overlap. Characteristics of males and females have been used for the accurate identification of most species (Nguyen \& Smart, 1996), although it has been shown that morphometrics of Steinernema species vary depending on the time of harvest (time after infective juveniles first appear) and whether the nematodes are reared in vitro or in vivo. These differences may complicate identification (Nguyen \& Smart, 1995). Despite several phylogenetic SSU and LSU rDNA analyses the position of Steinernematidae remains uncertain. In this paper we follow De Ley and Blaxter (2002) and place the family under the Strongyloidoidea within the Tylenchina, a placement also accepted by Holterman et al. (2006), Hunt (2007), Meldal et al. (2007) and Bert et al. (2008), although rejected by Nadler et al. (2006a).

\footnotetext{
* Corresponding author, e-mail: zojulia@yandex.ru
} 
The general anatomy of the female reproductive system is widely used as an important informative (diagnostic) character in nematode systematics (Seinhorst, 1968; Lorenzen, 1978; Geraert, 1983; Bert et al., 2002, 2003). However, the ultrastructure of this system has been examined in relatively few nematode taxa (Chitwood \& Chitwood, 1977; Foor, 1983; Hess \& Poinar, 1986; Bird \& Bird, 1991; Yushin \& Malakhov, 1997; Bert et al., 2006). Until now, all knowledge related to the general morphological organisation and fine structure of the reproductive system within the Steinernematidae is restricted to the very few remarks found in the species descriptions. In order to address this gap, the morphology of the female reproductive system in several representatives of the genus Steinernema was studied using light and electronic microscopy. We also attempt to apply the structure of the female reproductive system as an additional feature to clarify the taxonomical relationships within the genus.

\section{Materials and methods}

\section{MATERIAL STUDiED}

The female reproductive systems of six Steinernema species, viz., S. glaseri (Steiner, 1929), S. feltiae (Filipjev, 1934), S. carpocapsae (Weiser, 1955), S. arenarium (Artyukhovsky, 1967), S. affine (Bovien, 1937) and S. bicornutum Tallosi, Peters \& Ehlers, 1995, were studied using light and/or electron microscopy.

Infective juveniles of these species were received in the form of pure cultures from the Nematology laboratory of the Crop Protection Department, Agricultural Research Centre (DGB-CLO), Merelbeke, Belgium, and from the Department of Zoology, Sofia University, Bulgaria.

The greater wax moth larva, Galleria mellonella, was used for nematode inoculation and multiplication. Three to five larvae were placed in a Petri dish lined with filter paper. Each set of larvae was inoculated with $5 \mathrm{ml}$ of distilled water containing $\mathrm{ca} 100$ infective juveniles of the nematode species to be studied. Protected from evaporation with Parafilm ${ }^{\circledR}$, the Petri dishes were stored at room temperature for 3 days. After death, larvae were placed in plastic containers containing a shallow layer of distilled water. After 5-15 days the larvae were dissected in $0.9 \% \mathrm{NaCl}$ solution so as to extract adult females of Steinernema.

\section{LIGHT MICROSCOPY}

Four to six females of every species were put into a drop of $0.9 \%$ solution of $\mathrm{NaCl}$ on a glass slide and then cut with an oculist's scalpel, thereby leading to expulsion of the gut and gonad. After removal of most of the non-reproductive tissue a cover slip was applied to the preparation, which was then sealed with nail polish and studied using a light microscope (Olympus BX 51 or Polyvar) equipped with interference contrast. In order to assess the variability of the studied structure, this procedure was repeated until at least 20 preparations of each species were available for observation. It is possible that the dissection process could influence the size and shape of the cells due to changing osmomolarity. However, repeated dissections demonstrated that such factors are relatively constant within species. Original drawings were made using a drawing tube and images were captured with an Olympus C5060 digital camera.

\section{TRANSMISSION ELECTRON MICROSCOPY}

For transmission electron microscopy, adult females of $S$. feltiae were dissected with an oculist's scalpel to expel the reproductive system. Both reproductive system and whole females were fixed in $2.5 \%$ glutaraldehyde solution in $0.2 \mathrm{M}$ cacodylate buffer with $0.9 \% \mathrm{NaCl}$ and $0.5 \%$ magnesium chloride. In addition, whole females were fixed and cut into pieces containing the reproductive system. Fixed specimens were stored from 1 day to 1 week at $4^{\circ} \mathrm{C}$. Specimens were rinsed three times (15 min each rinse) in $0.2 \mathrm{M}$ cacodylate buffer with $0.9 \% \mathrm{NaCl}$ and distilled water, kept rotating for $1 \mathrm{~h}$ at room temperature and left overnight at $4^{\circ} \mathrm{C}$. Postfixation was done using $1 \%$ osmium tetroxide solution in 0.2 $\mathrm{M}$ cacodylate buffer and $0.9 \% \mathrm{NaCl}$. In this solution specimens were stored for $12 \mathrm{~h}$ at $4^{\circ} \mathrm{C}$ with continuous rotation. After that, specimens were rinsed in distilled water for $3 \times 15 \mathrm{~min}$. Specimens were dehydrated in two changes each of 30, 50, 70, 90 and $100 \%$ ethanol, each stage lasting $15 \mathrm{~min}$. Dehydrated specimens were placed in a mixture of Spurr resin and 100\% ethanol (ratio 1:3) for $3 \mathrm{~h}$ at room temperature with rotation. They were then placed in the same mixture (ratio $1: 1$ ) for $3 \mathrm{~h}$ at room temperature with rotation and then stored overnight in a mixture of Spurr resin and ethanol (ratio $3: 1$ ) at $4^{\circ} \mathrm{C}$. Finally, specimens were put into pure Spurr resin for 2 $\mathrm{h}$ at room temperature and $24 \mathrm{~h}$ at $4^{\circ} \mathrm{C}$ with continuous rotation. Embedding was done in fresh Spurr resin using $\mathrm{LKB}$ embedding moulds for 2 days at $60^{\circ} \mathrm{C}$. 
Ultrathin sections $(50-70 \mathrm{~nm})$ were made using a Reichert Ultracut E with glass knife. Sections were placed on copper grids covered with formvar. The sections were stained in a $1 \%$ aqueous solution of uranyl acetate for $15 \mathrm{~min}$ at room temperature. After washing in distilled water, sections were stained in lead citrate for $4 \mathrm{~min}$ at room temperature. Slides were viewed using Jeol JEM1010 and JEM-100S transmission electron microscopes.

\section{SCANNING ELECTRON MICROSCOPY}

For scanning electron microscopic observation, excised reproductive systems of $S$. carpocapsae and $S$. feltiae were transferred and fixed in freshly prepared $4 \%$ formaldehyde in phosphate buffered saline $(\mathrm{pH} 7)$ at room temperature. The reproductive systems were fixed overnight and subsequently dehydrated in 25, 50, 75 and $95 \%$ ethanol at $2 \mathrm{~h}$ intervals, followed by an overnight dehydration in absolute ethanol and final removal of the remaining water using silica gel. After critical point drying, using $\mathrm{CO}_{2}$ as the drying liquid (Blazers Union LPD 020) specimens were mounted and covered with $20 \mathrm{~nm}$ gold layer using a Blazers SCD 040. Examination was done with a Jeol JSM-840 scanning electron microscope.

\section{Results}

All examined Steinernema species share a similar general structure of the female reproductive system. The amphidelphic reproductive system consists of two similar branches, each branch being subdivided into three parts: a reflexed ovary, oviduct and uterus.

\section{STEINERNEMA ARENARIUM}

The long ovaries are filled with genital cells at different developmental stages. The proximal part of the ovary (Fig. 1A) is swollen and forms a sac 40-45 $\mu \mathrm{m}$ diam. which is filled with oocytes. Sperm cells may be found in this part of the ovary as well. The wall of this part of the ovary is formed from nucleate epithelial cells (Fig. 2C, inset) ca $25 \mu \mathrm{m}$ in diam.

The oviduct (Figs 1A; 2C) is ca $140 \mu \mathrm{m}$ long. The distal two-thirds are composed of two rows of rectangular epithelial cells which are $20 \mu \mathrm{m}$ long and contain nuclei ca $3.5 \mu \mathrm{m}$ in diam. The cells of the proximal part of the oviduct are polygonal and have interlaced cell boundaries.

The long uterus consists of two unequal parts that are separated from each other by a constriction (Fig. 1A). A few uterus cells surround the distal end of the oviduct (Fig.
2D). There are two microscopically dense cells (20 $\mu \mathrm{m}$ in diam.) on both sides of the distal end of the oviduct. The distal, smaller part of the uterus is $c a 170 \mu \mathrm{m}$ long and 65 $\mu \mathrm{m}$ across and is formed by large polygonal cells $20 \mu \mathrm{m}$ in diam. In this part of the uterus, giant sperm cells $\mathrm{ca} 30$ $\mu \mathrm{m}$ in diam. could be seen (Figs 1A; 2D). The remaining part of the uterus is formed from similar cells and, in the case of older females, filled with fertilised eggs. The uterus in all of the examined Steinernema species was composed of more than 200 cells. However, the exact number could not be determined with certainty.

\section{STEINERNEMA BICORNUTUM}

The wall of the ovary consists of flattened epithelial cells. Cell boundaries have not been observed using light microscopy. The distal part of the ovary is filled with oocytes forming a straight chain (Fig. 2A). The oviduct consists of two elongated cells 25-30 $\mu \mathrm{m}$ long having nuclei of 6-7 $\mu \mathrm{m}$ diam. (Figs 1B; 2B).

The most distal 10-14 wall cells (Fig. 1B) (diam. 25 $\mu \mathrm{m}$ ) of the uterus are polygonal in shape and in some cases have interlaced borders. They contain nuclei $5 \mu \mathrm{m}$ in diam. This part of the uterus is filled with round sperm cells 6-7 $\mu \mathrm{m}$ in diam. (Figs $1 \mathrm{~B} ; 2 \mathrm{~B}$ ). In older females, the remaining part of the uterus consists of large rectangular cells $(30 \mu \mathrm{m})$ and is filled with eggs.

\section{STEINERNEMA CARPOCAPSAE}

Scanning electron microscopy reveals that the surface of the distal half of the ovary is smooth and the borders between the cells are barely distinguishable. The next part of the ovary is formed by round cells (Fig. 3A, B) which have interlaced boundaries. The size of these cells varies from $14-17 \mu \mathrm{m}$ in diam. The rest of the ovary shows flattened rectangular cells $c a 10 \mu \mathrm{m}$ across (Fig. 3C). The relatively short (ca $50 \mu \mathrm{m}$ long) narrow oviduct (23-25 $\mu \mathrm{m}$ diam.) follows on from the ovary (Figs 1C; 3A). It consists of rectangular cells that tend to be narrower towards the oviduct-uterus connection. At the oviduct-uterus junction the uterus wall consists of polygonal cells (diam. 10-15 $\mu \mathrm{m}$ ) that are flattened and may have interlaced boundaries. The surface of the distal part of the uterus, as seen by SEM, is formed by flattened epithelial cells and is followed by a broader part of the wall that consists of polygonal cells $c a 40 \mu \mathrm{m}$ in diam.

\section{STEINERNEMA FELTIAE}

The description made using TEM is based on the anterior branch of the didelphic reproductive system 


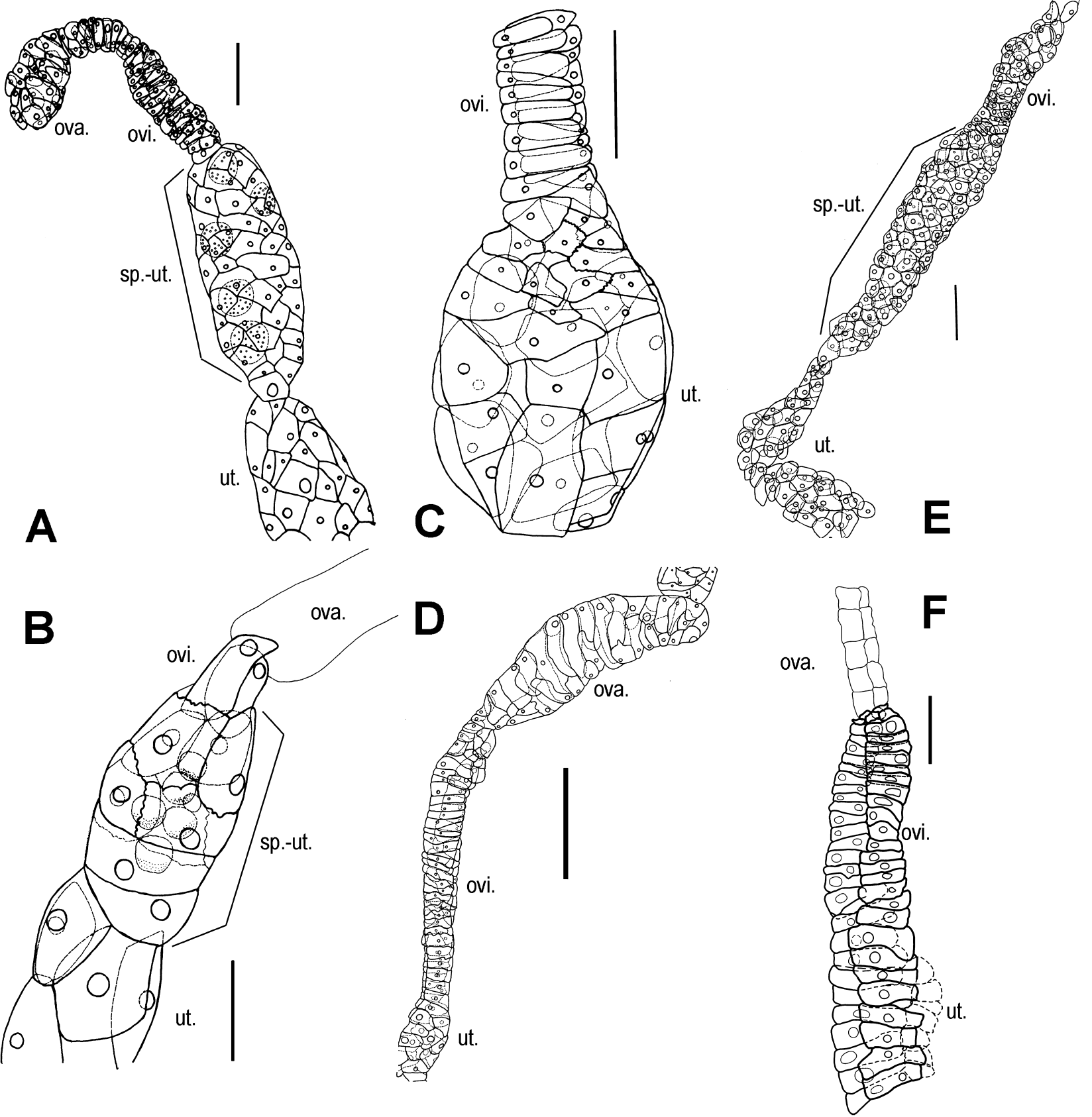

Fig. 1. Oviduct-uterus region of Steinernema spp. A: Steinernema arenarium; B: S. bicornutum; C: S. carpocapsae; D: S. feltiae; E: S. glaseri; F: S. affine. Abbreviations: ova. = end of ovary; ovi. =oviduct; sp.-ut. = spermatheca-uterus complex; ut. = beginning of uterus. (Scale bars: $A, E=40 \mu \mathrm{m} ; B, F=30 \mu \mathrm{m} ; C, D=20 \mu \mathrm{m}$.)

Fig. 2. Female reproductive system of Steinernema spp. A: Chain of oocytes $(O)$ in ovary of $\mathrm{S}$. bicornutum $(N=$ nucleus $)$; B: Oviduct (ovi.) of S. bicornutum consisting of two cells connected with spermatheca-uterus complex (sp.-ut.) filled with spermatozoa (sp); $C$ : Oviduct (ovi.) of S. arenarium consisting of two layers of cells (outer layer indicated by black arrowhead, inner one by white arrowhead; sp.-ut. = spermatheca-uterus complex). Inset: Wall (arrows) of ovary (ova.); D: Sphincter-like structure (star) at connection between oviduct (ovi.) and uterus of S. arenarium (sp=giant spermatozoa). (Scale bars: $A, B=30 \mu \mathrm{m} ; \mathrm{C}$, D, Inset $=10 \mu \mathrm{m}$.) 

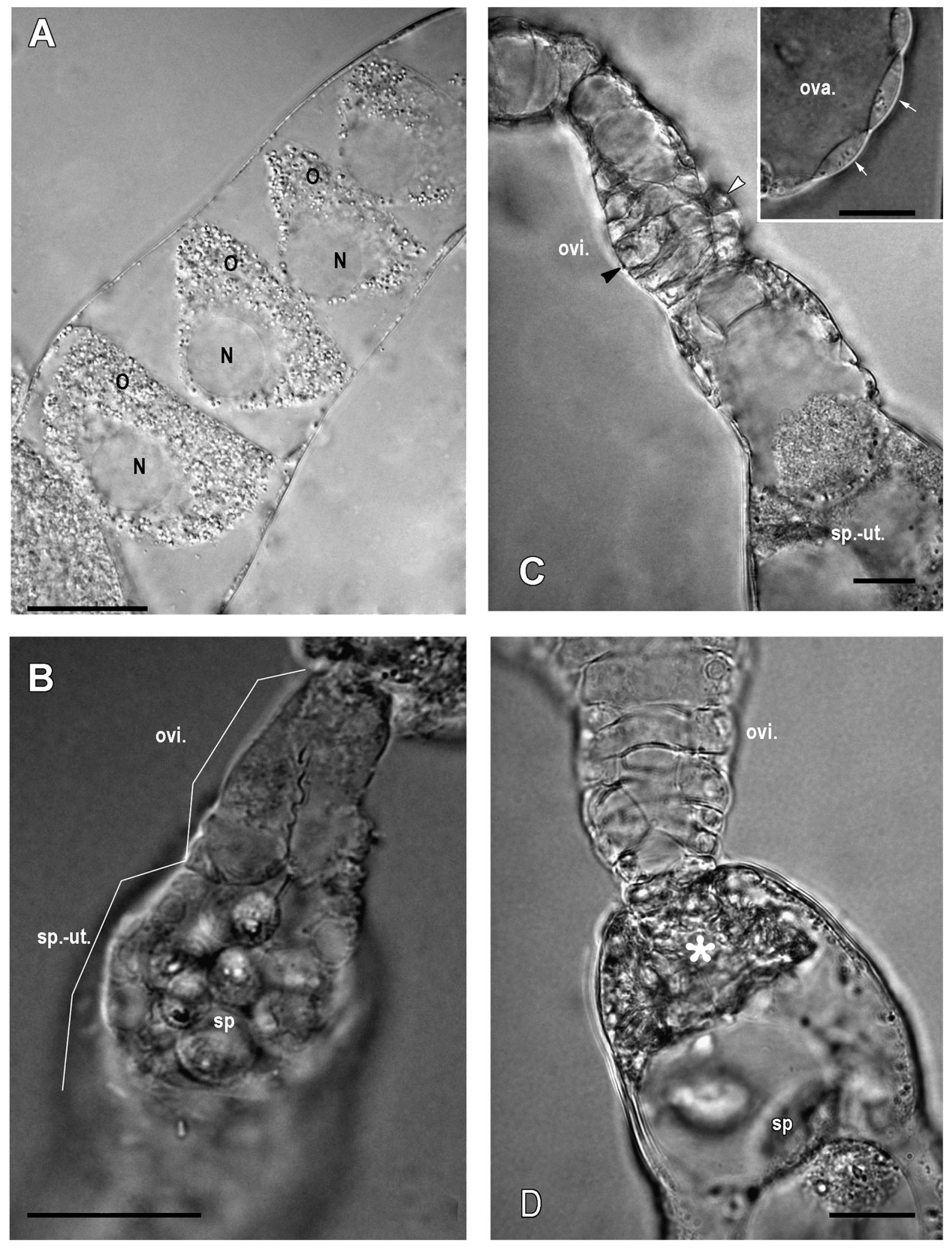


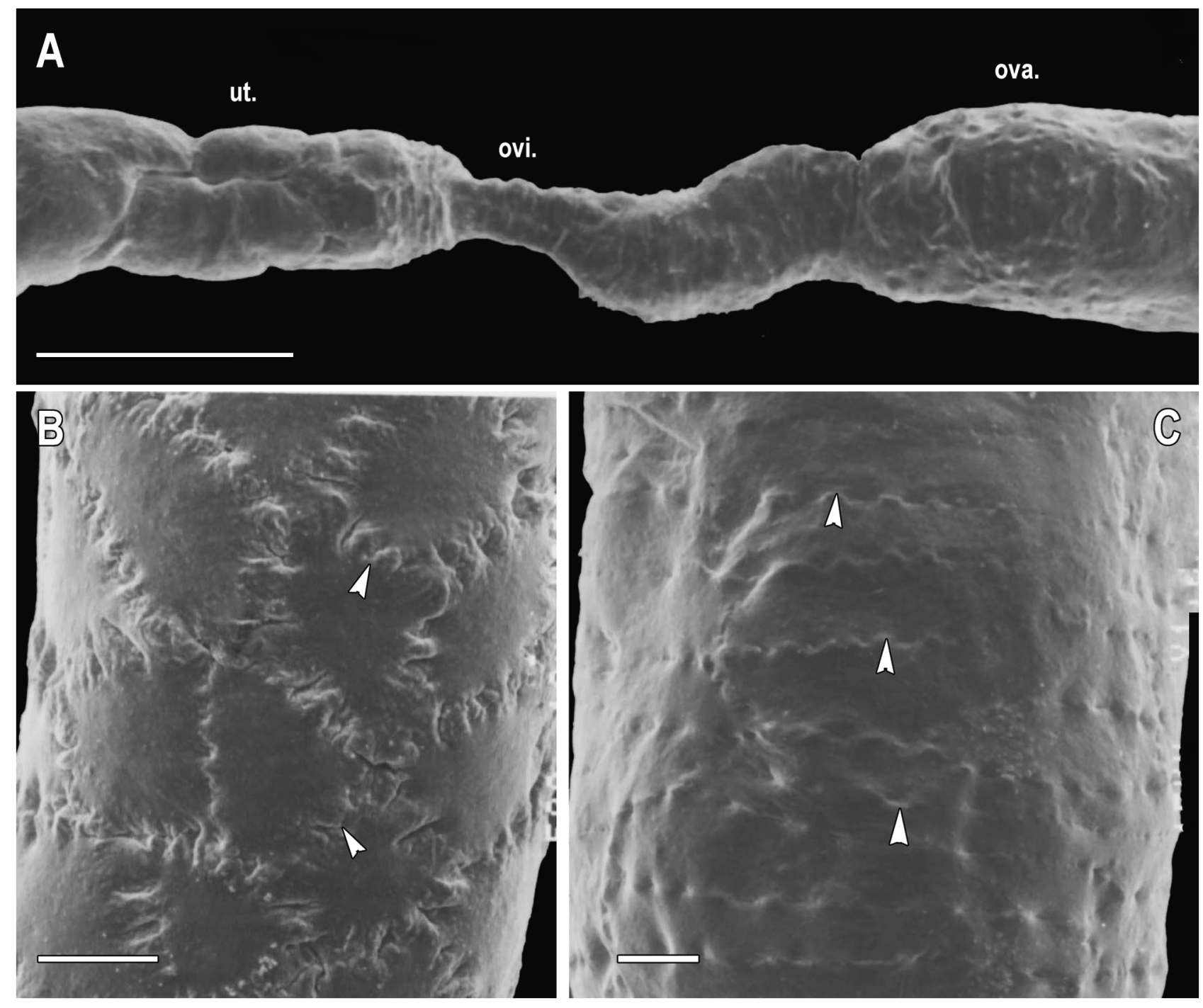

Fig. 3. Steinernema carpocapsae. Scanning electron microscopy. A: Fragment of female reproductive system in oviduct region (ova. $=$ ovary; ovi. $=$ oviduct; $u t .=$ uterus); B: Ovarial wall of tubular part of ovary; : Wall of ovarial sac. Arrowheads indicate cell boundaries. (Scale bars: $A=100 \mu \mathrm{m} ; B, C=10 \mu \mathrm{m}$.)

(Fig. 5). All the cells of the gonadal wall are epithelial in nature and are attached to a basal lamina.

The ovary of $S$. feltiae comprises epithelial cells that increase in size in the direction of the oviduct. SEM study shows that the smooth, distal, part of the ovary is formed from epithelial cells that lack visible borders (Fig. 4A). The wall of the central, gradually widening, region of the ovary consists of polygonal cells with interlaced cell boundaries (Fig. 4B). A sharp constriction separates the distal part of the ovary from the following narrower tube (Fig. 4A) which is ca $140 \mu \mathrm{m}$ long and formed from flattened rectangular cells with clear interlaced boundaries. The last third of the ovary consist of large, more or less rectangular cells, ca $50 \mu \mathrm{m}$ long. Several swellings could be found in this region of the ovary that is often filled with oocytes (Figs 1D; 4A).

The ovary is followed by the long (up to $200 \mu \mathrm{m}$ ) oviduct (Figs 1D; 4C). The oviduct cells are 20-25 $\mu \mathrm{m}$ long and 4.5-5 $\mu \mathrm{m}$ across. Arrangement of the cells is irregular and the number of cells in virtual cross section varies from four to six. Closer to the connection with the uterus, the oviduct cells become longer and may be as 

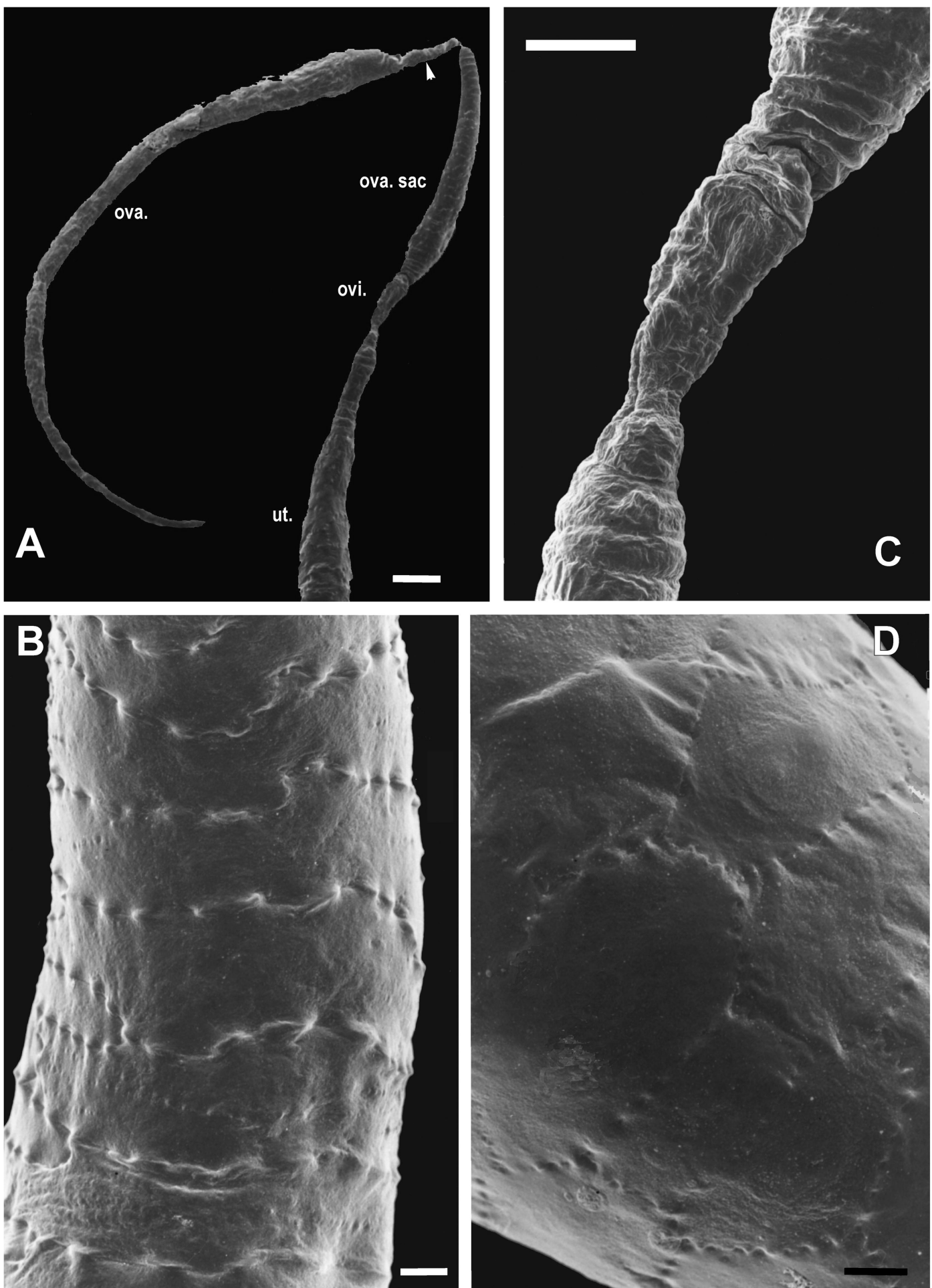

Fig. 4. Steinernema feltiae. Scanning electron microscopy. A: Female reproductive system, overview. Ovary (ova.), ovarial sac (ova. sac), oviduct (ovi.), uterus (ut.); B: Ovarial wall; C: Fragment of reproductive system with oviduct; D: Uterine wall. (Scale bar: A = $100 \mu \mathrm{m} ; B-D=10 \mu \mathrm{m}$.) 

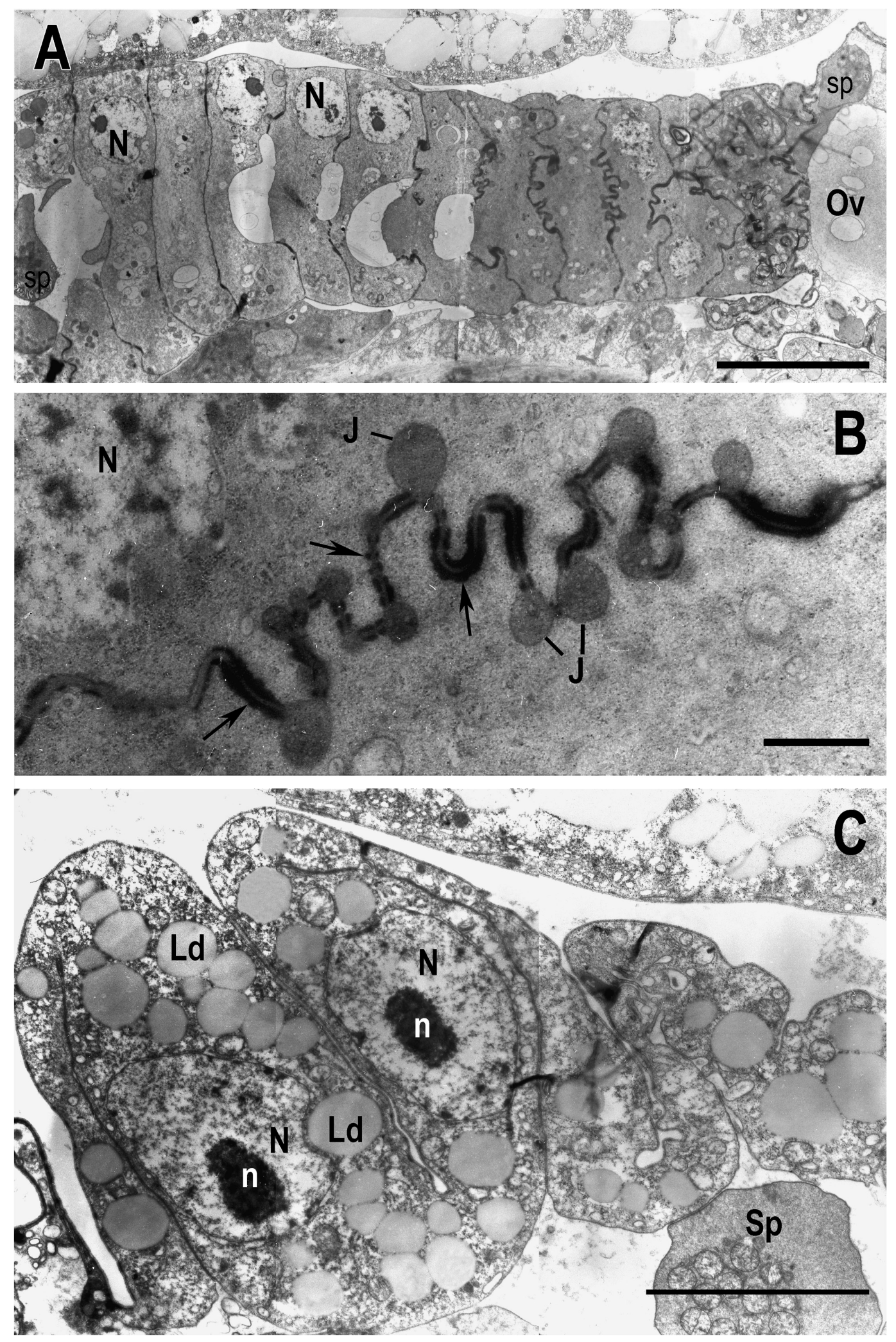
long as $8 \mu \mathrm{m}$. TEM observations show that the oviduct wall is lined with flattened rectangular cells with dense cytoplasm (Fig. 5A). A relatively large (3-4 $\mu \mathrm{m}$ in diam.) round or ovoid nucleus with non-condensed chromatin and well distinguished nucleolus (1-1.5 $\mu \mathrm{m}$ in diam.) occupies a peripheral position in the cell. The electron dense cytoplasm of the cells contains few mitochondria, cisternae of rough endoplasmic reticulum, Golgi bodies and electron transparent vacuoles. The oviduct cells are connected to each other by distinct cellular junctions (Fig. 5B). Parallel electron-dense bands 6-10 nm thick are deposed on the membranes in patches along the entire length of the intercellular contacts (Fig. 5A, B). Cellular organelles are generally not associated with the cortical cytoplasm. Mature spermatozoa could be found both in the oviduct and distal portion of the ovary (Fig. 5A).

No distinct border between oviduct and uterus could be observed. The uterus is folded many times in the body cavity of the worm. The wall of the uterus is homogenous along its length and formed from polygonal cells $\mathrm{ca}$ 15$20 \mu \mathrm{m}$ in diam. with interlaced boundaries (Figs 1D; 4D; 5C). At least two nuclei, 4-5 $\mu \mathrm{m}$ in diam., could be found in a single uterus cell. The nucleus contains dispersed chromatin and a large nucleolus (1-2 $\mu \mathrm{m}$ in diam.). The cytoplasm of the uterus cells is filled with mitochondria, cisternae of rough endoplasmic reticulum and Golgi bodies. Large lipid drops of different size (0.5$1.4 \mu \mathrm{m}$ diam.) are densely packed in the cytoplasm of the uterine wall cells.

\section{STEINERNEMA GLASERI}

The wall of the ovary consists of thin epithelial cells. Several swellings (Fig. 1E) containing oocytes were observed in the proximal region of the ovary in older females. The oviduct is 100-120 $\mu \mathrm{m}$ long and consists of polygonal cells $c a 15 \mu \mathrm{m}$ in diam. These cells display a variable arrangement. The oviduct gradually transforms into the uterus and no clear border between uterus and oviduct could be detected. The uterus consists of two parts separated by a constriction. The smaller, distal part is $c a$ 240-250 $\mu \mathrm{m}$ long and $44 \mu \mathrm{m}$ diam. Polygonal epithelial cells (15-17 $\mu \mathrm{m}$ in diam.) form the wall of the uterus
(Fig. 1E). Giant sperm cells could be seen in the distal part of the uterus.

\section{STEINERNEMA AFFINE}

The wall of the ovary consists of large (13-15 $\mu \mathrm{m}$ in diam.) irregularly arranged rectangular cells with clear boundaries (Fig. 1F). The oviduct is $100-110 \mu \mathrm{m}$ long and consists of two rows of flattened, rectangular, cells 18$22 \mu \mathrm{m}$ long and 5-8 $\mu \mathrm{m}$ across. The uterus, immediately following the oviduct, is $45-50 \mu \mathrm{m}$ wide in the distal portion (Fig. 1F). The uterus is devoid of swellings. No spermatozoa were observed in the uterus.

\section{Discussion}

Although the basic division of the nematode female genital tube into ovary, oviduct and uterus is well known, the detailed morphology of the female gonads has never been studied in Steinernema species, even using light microscopy. Except for S. bicornutum, all species studied show an overall similarity in reproductive system architecture, i.e., a swollen proximal region formed by the ovaries, an oviduct consisting of irregular rows with two to four cells in cross-section and a uterus divided into two morphologically distinguishable parts (except $S$. carpocapsae). Such a gonoduct structure is distinctive from any other known nematode gonoduct. In particular, the arrangement of the oviduct cells in mainly long irregular rows with two to four cells in cross-section (except in S. bicornutum) is, according to current knowledge, unique within the Rhabditida. Because of this uniqueness, the absence of a characteristic gonoduct system for early diverging Tylenchina (Bert et al., 2008), and the fact that in rhabditid nematodes the gonoduct structure even varies significantly across genera (Geraert et al., 1980), it is difficult to compare the Steinernema gonoduct structure with putatively closed related taxa. Thus, the gonoduct structure does not provide any morphological clues to the molecular based discussion about the phylogenetic position of Steinernema, i.e., within (De Ley \& Blaxter, 2002) or outside (Nadler et al., 2006a) the Tylenchina. However, the overall similarity in gonoduct structure within the genus

Fig. 5. Steinernema feltiae. Transmission electron microscopy. A: Longitudinal section through part of oviduct consisting of flattened cells with large nucleus $(N)$ with nucleolus. Electron dense cytoplasm contains few mitochondria, cisternae of RER, Golgi bodies and electron-transparent vesicles. Spermatozoa (sp) are found both in uterus and ovary (ov); B: Junctions (J) associated with banded junctions (arrows). Abbreviation: $N=$ nucleus; $C$ : Longitudinal section through uterine wall. Abbreviations: $L d=l i p i d$ drops, $N=$ nucleus, $n=$ nucleolus, $S p=$ spermatozoon. (Scale bars: $A=10 \mu \mathrm{m} ; B=1 \mu \mathrm{m} ; C=5 \mu \mathrm{m}$.) 
may be an additional argument supporting the coherence of the genus Steinernema, a feature also shown from other morphological and molecular studies (Stock et al., 2001; Spiridonov et al., 2004).

All Steinernema species have reflexed telogonic ovaries that have one or more swellings in the proximal region. These swellings are filled with oocytes and are similar to the ovarial sac of other nematodes (Bird \& Bird, 1991; Gibbons, 2002). In the case of S. feltiae and S. carpocapsae more than one ovarial sac could be observed. These sacs are separated from each other by a simple narrowing in the case of $S$. carpocapsae or, as in the case of $S$. feltiae, the ovarial wall can form a tube. We have never observed oocytes in the narrow tubular part of the ovary, a fact which may be an indication that the function of this tube is to pass the oocytes from one part of the ovary to another. It was shown for $S$. arenarium and $S$. feltiae in the current work, and already observed in some Dorylaimida and Enoplida (Turk, 1903), that spermatozoa can be found throughout the female tract, even in the ovary. Probably, the presence of this constriction between the sacs is necessary to prevent premature movement of ripening oocytes to that part of the genital system where they may meet spermatozoa.

Electron-microscope observation has shown that the wall of the ovary of $S$. feltiae consists of flattened epithelial cells. The ovary wall has been described for many nematodes as a sheath of simple, flattened, epithelial or myoepithelial cells stretched along the ovary (Harada et al., 1970; Foor, 1983; Strome, 1986; Van de Velde \& Coomans, 1988; Yushin \& Malakhov, 1997; Endo et al., 1999; Bert et al., 2007). It also displays secretory activity (Yushin \& Malakhov, 1997) and could also form the structures that appear to function as a valve (Bert et al., 2003). However, we were not able to find myoepithelial cells in the ovarial wall of Steinernema species and additional studies are necessary to determine the exact function of the ovary wall cells.

The oviduct, a constriction between ovary and uterus without a visible lumen, has been described as a remarkably evolutionary-stable structure of fundamental importance for nematode systematics (Geraert, 1983). However, our data contradict the general structure of the 'Secernentea' oviduct that comprises two cell rows (Geraert, 1983). With the exception of S. bicornutum, all species studied have an oviduct with an irregular arrangement of cells. The general gonoduct structure is strikingly different to that of other nematodes in that it does not provide an obvious morphological clue to infer the phylogenetic posi- tion of the Steinernematidae. Furthermore, the morphology of the oviducts differs from species to species. Mostly, such differences concern the length of the oviduct which varies from very long in $S$. feltiae $(200 \mu \mathrm{m})$, where it consists of more than 70 cells, to extremely short in $\mathrm{S}$. bicornutum (only two cells). A visible lumen between the oviduct cells is lacking and we did not observe oocytes in this part of the gonoduct. Though the secretory nature of the cells of the oviduct has been shown in a number of papers (Lee \& Lestan, 1971; Yuen, 1971; Adamson, 1983; Foor, 1983; Yushin \& Malakhov, 1997), the cells of the oviduct of $S$. feltiae studied with TEM show no secretory activity. At the same time, dense, homogenous cytoplasm mostly lacking organelles, as in S. feltiae, is characteristic of smooth muscle cells (Rowan et al., 1981; Wada et al., 1999). Thus, we may presume a conducting function of the oviduct with cells able to squeeze or move apart during oocyte passage. Several nematode taxa have a sphincter at the transition between the oviduct and uterus (Hope, 1974). In the case of Steinernema species we found sphincter-like structures only in $S$. arenarium (Fig. 2D). Steinernema glaseri and S. feltiae show a more gradual transition from oviduct to uterus and TEM studies revealed no sphincter or valve between the oviduct and uterus.

Special attention is paid to the spermatheca as it has particular value as a taxonomic character for a number of nematodes (Geraert, 1981, 1983; Baldwin \& Schouest, 1990; Bert et al., 2002; Ryss, 2002). However, a separate spermatheca was not observed for the Steinernema species studied. In this genus, a spermatheca has been described only for $S$. hermaphroditum in the hermaphrodite generation (Stock et al., 2004). The authors described the spermatheca as a glandular formation filled with sperm cells. From the given description it is not clear whether this structure is a morphologically or functionally separated structure, or just a part of the uterus temporarily filled with spermatozoa.

In most of the nematodes studied (with the exception of $S$. carpocapsae and $S$. affine) the uteri always have a swollen distal part and, in all of them (except $S$. feltiae), this part is separated from the remaining uterus by a constriction. Usually this part of the uterus is filled with spermatozoa. As the spermatozoa in Steinernema were found in different parts of the gonad, ranging from the very distal part of the uterus (Spiridonov et al., 1999) to the distal region of the ovary (Turk, 1903; present study), we do not interpret the distal uterus swelling as a separate spermatheca. We prefer to use the term 'spermatheca- 
uterus complex' to accentuate the tendency of this group to form a special chamber for sperm storage yet one which is not secured as a permanent morphological and functional structure. As has been shown in many nematode studies, fertilisation of the oocytes takes place in the proximal part of the uterus (e.g., Bird \& Bird, 1991) and the observed swellings may serve as fertilisation chambers.

The wall of the uterus comprises cells with high secretory activity, as evidenced by the accumulation of large lipid drops in the cell cytoplasm. In previous studies, differences were found between sperm cells from the proximal and distal part of the uterus (Spiridonov, pers. comm.). Spermatozoa from the distal part of the uterus resemble those from the vas deferens, whereas spermatozoa from the proximal chamber differ. It is, therefore, possible that sperm activation sperm takes place in the distal swellings of the uterus due to the secretory activity of the wall cells. The slight constriction between the two parts of uterus found in S. bicornutum, S. glaseri and $S$. arenarium may also prevent the reflux of sperm from this region during the passage of eggs, an idea that has also been proposed for some dorylaimid species (Grimaldi-De Zio et al., 1979).

Based on morphology and multi-gene molecular analysis, the genus Steinernema has been subdivided into five major clades (Stock et al., 2001; Spiridonov et al., 2004; Nadler et al., 2006b): I, 'intermedium-affine'; II, 'carpocapsae-tami-scapterisci'; III, 'feltiae-krausseioregonense'; IV, 'bicornutum-ceratophorum-riobrave'; and V, 'glaseri-arenarium-karii-longicaudatum'. This division is supported by the morphology of the infective juvenile, morphology of the sperm cells in the uterus and molecular analysis based on nuclear and mitochondrial rDNA (SSU, LSU; 12S, cox 1). Despite the fact that the composition of the five clades in Nadler et al. (2006b) and Spiridonov et al. (2004) do not exactly correspond, the species of the present study are consistent with both studies. Here, we discuss if these clades can also be characterised by gonoduct morphology.

Although the female reproductive systems of the Steinernema species studied (with the exception of the S. bicornutum) show clear similarities in gonad architecture, some characters show a distinct intra-generic variability. Steinernema glaseri and S. arenarium, two species from the same clade ('glaseri-arenarium-karii'), are characterised by having a single proximal ovarial sac, a medium length oviduct (100-150 $\mu \mathrm{m}$ long) comprised of irregular cells rows and a uterus subdivided into two parts, viz., a distal spermatheca-uterus complex and the remaining part of the uterus. Steinernema affine, a representative of the 'intermedium-affine' clade, is characterised by the absence of ovarial sacs, medium length oviduct (100$150 \mu \mathrm{m}$ long) and uterus lacking a uterine sac. Steinernema carpocapsae, belonging to the 'carpocapsae-tamiscapterisci' clade, is characterised by the presence of several ovarial sacs, short oviduct ( $<70 \mu \mathrm{m}$ long) and uterus lacking a uterine sac. Steinernema feltiae, a member of the 'feltiae-kraussei-oregonense' group, can be recognised by having several ovarial sacs, very long ( $>180 \mu \mathrm{m}$ long) oviduct and the lack of the constriction between the spermatheca-uterus complex and the remaining part of the uterus. The most deviant nematode, S. bicornutum from the 'bicornutum-ceratophorum-riobrave' clade, is characterised by the presence of only one ovarial sac, an extremely short oviduct consisting of only two cells and a uterus subdivided into two unequal parts.

These results point to a possible congruence between the gonoduct characters and known molecular phylogenetic hypothesis within Steinernema. However, since in this study only one representative of each major clade was studied (with exception of the 'glaseri-arenarium-kariilongicaudatum' clade), we cannot infer from our results if members of the same clade have the same gonoduct morphology. Nevertheless, for the 'glaseri-arenarium-kariilongicaudatum' clade, the presence of a single ovarial sac, oviduct of intermediate length and uterus with a sac may be characteristic. Additional investigations of the female reproductive system of a wider range of species will probably provide extra information either to support or disprove this clade-division.

As shown previously to be a general tendency, a short oviduct consisting of only a few cells characterises the supposedly more primitive nematode groups. For example, in the direction Enoplida $\rightarrow$ Mononchida $\rightarrow$ Dorylaimida, the number of oviduct cells increases from 214 (Enoplida $\rightarrow$ Mononchida) to 17-48 (Dorylaimida) in concert with supposedly advanced morphological characters (Gagarin \& Chizhov, 1993). A trend of increasing number of gonoduct cells has also been shown for the family Anguinidae (Brzeski, 1998) and for the Heteroderinae (Bert et al., 2002). From this point of view, S. bicornutum should have the most ancestral oviduct structure (it is composed of only two cells), contrary to its phylogenetic position embedded within Steinernema. However, the exact character polarity of the number of oviduct cells remains to be analysed in the presence of a resolved phylogeny that includes related taxa. 
At present, more than 50 species of Steinernema nematodes have been described (Hunt, 2007). Previously, identification of Steinernema species was done by using standard morphological methods and the morphology of infective juveniles and males was mostly used for taxonomical purposes. But identification of these nematodes by morphology and morphometry is rarely straightforward (Liu \& Berry, 1996; Hominick et al., 1997) as that type of approach requires the examination of numerous characters, some being difficult to observe (Liu et al., 1999). This problem is now especially acute as so many new species have been described during the last decade. All of these descriptions show comparatively limited morphological variation with overlapping of most morphometric characters. Some morphological characters are useful for distinguishing species or groups of species within Steinernema, e.g., lateral fields (Hominick et al., 1997; Mráček \& Bednarek, 1991), amoeboid sperm cells (Spiridonov et al., 1999) and morphology of the spicules and gubernaculum (Nguyen \& Smart, 1997). Application of molecular sequencing data in Steinernema taxonomy shows promising results, but is still imperfect because of the requirement for relatively complicated equipment, intraand inter-specific variability of markers, etc. (Stock \& Reid, 2004). Despite all the promising new methods, adequate morphological keys are still essential (Hominick et al., 1997). Hence, the initial results of this study of the structure of the female reproductive system of Steinernema species indicate that cellular morphology may have taxonomical applications and could be used as an additional character for species delineation and identification within a morphologically conserved genus.

\section{Acknowledgements}

The authors thank Rita Van Driessche and Myriam Claeys for technical assistance, and Ansari Minshad Ali, Sergei Spiridonov and Denis Gradinarov for their generous supply of specimens. We are especially grateful to Sergei Spiridonov for his stimulating ideas and comments at the beginning of this study. The research was supported by Grants N 08-04-00209-a and N 08-04-00580-a from the Russian Foundation for the Basic Research, Grants N 06-III-A-06-173 and N 06-III-B-06-201 from Far Eastern Branch of the Russian Academy of Sciences and grant 1.5.090.05 from the Research Foundation-Flanders (FWO).

\section{References}

ADAMSON, M.L. (1983). Ultrastructural observations on oogenesis and cell formation in Gyrinicola batrachiensis (Walton, 1929) (Nematoda: Oxyurida). Parasitology 86, 489-499.

Ansari, M.A., Waeyenberge, L. \& Moens, M. (2007). Natural occurrence of Steinernema carpocapsae Weiser, 1955 (Rhabditida: Steinernematidae) in Belgian turf and its virulence to Spodoptera exigua (Lepidoptera: Noctuidae). Russian Journal of Nematology 15, 21-24.

BALDWIn, J.G. \& Schouest, L.P. (1990). Comparative detailed morphology of the Heteroderinae Filip'ev \& Schuurmans Stekhoven, 1941, sensu Luc et al. (1998): phylogenetic systematics and revised classification. Systematic Parasitology 15, 81-106.

Bert, W., Karssen, G., Van Driessche, R. \& Geraert, E. (2002). The cellular structure of the female reproductive system within Heteroderinae and Meloidogyninae (Nematoda). Nematology 4, 953-963.

Bert, W., Van Gansbeke, R., Claeys, M., Geraert, E. \& Borgonie, G. (2003). Comparative morpho-anatomical studies of the female gonoduct within the Pratylenchidae (Nematoda: Tylenchina). Nematology 5, 293-306.

Bert, W., Claeys, M. \& Borgonie, G. (2006). The comparative cellular architecture of the female gonoduct among Tylenchoidea (Nematoda: Tylenchina). Journal of Nematology 38, 362-375.

Bert, W., Vangestel, S., Houthoofd, W., Van GansBEKE, R. \& BorgOnIE, G. (2007). The somatic female gonad of Cephalobidae (Nematoda): cellular architecture and associated function. Nematology 9, 285-297.

Bert, W., Leliaert, F., Vierstraete, A.R., VanFleteren, J.R. \& Borgonie, G. (2008). Molecular phylogeny of the Tylenchina and evolution of the female gonoduct (Nematoda: Rhabditida). Molecular Phylogenetics and Evolution, in press.

BIRD, A.F. \& BIRD, J. (1991). The structure of nematodes. San Diego, CA, USA, Academic Press, 316 pp.

BRZESKI, M.V. (1998). Nematodes of Tylenchina in Poland and temperate Europe. Warsaw, Poland, Muzeum I Instytut Zoologii Polska Akademia Nauk, 397 pp.

Chitwood, B.G. \& Chitwood, M.B. (1977). Introduction to nematology. Baltimore, London \& Tokyo, University Park Press, 334 pp.

De LEY, P. \& BlaXter, M.L. (2002). Systematic position and phylogeny. In: Lee, D.L. (Ed.). The biology of nematodes. London, UK, Taylor \& Francis, pp. 1-30.

ENDO, B.Y., ZUNKE, U. \& WERGIN, W.P. (1999). Ultrastructure of the female reproductive system of the lesion nematode, Pratylenchus penetrans (Nemata: Pratylenchidae). Journal of the Helminthological Society of Washington 66, 155-175.

Foor, E.W. (1983). Nematoda. In: Adiyodi, K.G. \& Adiyuody, R.G. (Eds). Reproductive biology of invertebrates, Vol. 1. 
Oogenesis, oviposition, and oosorption. Chichester, UK, John Wiley \& Sons, pp. 223-256.

Gagarin, V.G. \& Chizhov, V.N. (1993). [Some data on structure the female genital system in free-living nematodes and the main trends of its evolution.] Zoologichesky Zhurnal 72, 27-39.

GAUGLER, R. \& KAYA, H.K. (1990). Entomopathogenic nematodes in biological control. Boca Raton, FL, USA, CRC Press, 365 pp.

GERAERT, E. (1981). The female reproductive system in nematode systematics. Annales de la Société Royale Zoologique de Belgique 110, 73-86.

GERAERT, E. (1983). The use of the female reproductive system in nematode systematics. In: Stone, A.R., Platt, H.M. $\&$ Khalil, L.F. (Eds). Concepts in nematode systematics. London, UK, Academic Press, pp. 73-84.

Geraert, E., Sudhaus, W. \& Grootaert, P. (1980). The structure of the female genital apparatus in the order Rhabditida (Nematoda). Annales de la Société Royale Zoologique de Belgique 109, 91-108.

GibBons, L.M. (2002). General organisation. In: Lee, D.L. (Ed.). The biology of nematodes. London \& New York, Taylor \& Francis, pp. 31-59.

Grimaldi-De Zio, S., D’Addabbo-Gallo, M., LamBerti, F. \& Morone-De LuCiA, M.R. (1979). The " $Z$ " differentiation in Xiphinema. A hypothesis of its function relation to amphigony. Nematologica 25, 36-41.

Harada, R., Maeda, T., Nakashima, A., Sadokata, Y., Ando, M., Yonamine, K., Otsuji, Y. \& Sato, H. (1970). Electron microscopical studies on the mechanism of oogenesis and fertilization in Dirofilaria immitis. In: Sasa, M. (Ed.). Recent advances in research on filariosis and schistosomiasis in Japan. Baltimore, MD, USA, University Park Press, pp. 99-121.

HESS, R. \& POINAR JR, G.O. (1986). Ultrastructure of the genital ducts and sperm behavior in the insect parasitic nematode, Heterorhabditis bacteriophora Poinar (Heterorhabditidae: Rhabditida). Revue de Nématologie 9, 141-152.

Holterman, M., VAN DER WurfF, A., VAN DEN ElSEN, S., van Megen, H., Bongers, T., Holovachov, O., BAKKer, J. \& Helder, J. (2006). Phylum-wide analysis of SSU rDNA reveals deep phylogenetic relationships among nematodes and accelerated evolution toward crown clades. Molecular Biology and Evolution 23, 1792-1800.

Hominick, W.M., Briscoe, B.R., Garcia Del Pino, F., Heng, J., Hunt, D.J., Kozodoy, E., Mráček, Z., Nguyen, K.B., Reid, A.P., Spiridonov, S., Stock, P., Sturhan, D., Waturu, C. \& Yoshida, M. (1997). Biosystematics of entomopathogenic nematodes: current status, protocols and definitions. Journal of Helminthology 71, 271-198.

Hope, W.D. (1974). Nematoda. In: Giese, A.C. \& Pearse J.S. (Eds). Reproduction of marine invertebrates, Vol. I.
Acoelomate and pseudocoelomate metazoans. San Diego, CA, USA, Academic Press, pp. 391-496.

HunT, D.J. (2007). Overview of taxonomy and systematics. In: Nguyen, K.B. \& Hunt, D.J. (Eds). Entomopathogenic nematodes: systematics, phylogeny and bacterial symbionts. Nematology Monographs and Perspectives, vol. 5. Leiden, The Netherlands, Brill, pp. 27-57.

KAYA, H.K. \& GAUGLER, R. (1993). Entomopathogenic nematodes. Annual Review of Entomology 38, 181-206.

LeE, D.L. \& Lestan, P. (1971). Oogenesis and egg shell formation in Heterakis gallinarum (Nematoda). Journal of Zoology 164, 189-196.

LIU, J. \& BERRY, R.E. (1996). Steinernema oregonensis n. sp. (Rhabditida: Steinernematidae) from Oregon, USA. Fundamental and Applied Nematology 19, 375-380.

LIU, J., BERRY, R.E. \& BLOUIN, M.S. (1999). Molecular differentiation and phylogeny of entomopathogenic nematodes (Rhabditidae and Steinernematidae) based on ND4 gene sequences of mitochondrial DNA. Journal of Parasitology 85, 709-715.

LORENZEN, S. (1978). New and known gonadal characters in free-living nematodes and the phylogenetic implications. Zeitschrift für Zoologische Systematik und Evolutionsforschung 16, 108-115.

Meldal, B.H.M., Debenham, N.J., De Ley, P., De Ley, I.T., Vanfleteren, J.R., Vierstraete, A.R., Bert, W., Borgonie, G., Moens, T., Tyler, P.A., Austen, M.C., BlaXter, M.L., Rogers, A.D. \& Lambshead, P.J.D. (2007). An improved molecular phylogeny of the Nematoda with special emphasis on marine taxa. Molecular Phylogenetics and Evolution 42, 622-636.

MrÁČEK, Z. \& BEDNAREK, A. (1991). The morphology of lateral fields of infective juveniles of entomogenous nematodes of the family Steinernematidae (Rhabditida). Nematologica 37, 63-71.

Nadler, S.A., De Ley, P., Mundo-Ocampo, M., Smythe, A.B., Stock, S.P., Bumbarger, D., AdAms, B.J., DE Ley, I.T., Holovachov, O. \& Baldwin, J.G. (2006a). Phylogeny of Cephalobina (Nematoda): Molecular evidence for recurrent evolution of probolae and incongruence with traditional classifications. Molecular Phylogenetics and Evolution 40, 696-711.

NAdler, S.A., Bolotin, E. \& Stock, S.P. (2006b). Phylogenetic relationships of Steinernema Travassos, 1927 (Nematoda: Cephalobina: Steinernematidae) based on nuclear, mitochondrial and morphological data. Systematic Parasitology 63, 161-181.

NGuYen, K.B. \& SMART, G.C. (1992). Addendum to the morphology of Steinernema scapterisci. Journal of Nematology 24, 187-199.

Nguyen, K.B. \& SMart, G.C. (1995). Morphometrics of infective juveniles of Steinernema, Heterorhabditis bacteriophora (Nemata: Rhabditida). Journal of Nematology 27, 206212. 
NGUYen, K.B. \& SMART, G.C. (1996). Identification of entomopathogenic nematodes in the Steinernematidae and Heterorhabditidae (Nemata: Rhabditida). Journal of Nematology 28, 286-300.

NGUYEN, K.B. \& SMART, G.C. (1997). Scanning electron microscope studies of spicules and gubernacula of Steinernema spp. (Nemata: Steinernematidae). Nematologica 43, 465-480.

ROWAN, R.A., BEVAN, R.D. \& BEVAN, J.A. (1981). Ultrastructural features of the innervation and smooth muscle of the rabbit facial vein, and their relationship to function. Circulation Research 49, 1140-1151.

RYSS, A.Y. (2002). Genus Pratylenchus Filipjev (Nematoda: Tylenchida: Pratylenchidae): multientry and monoentry keys and diagnostic relationships. Zoosystematica Rossica 10, 1125.

SeInhorst, J.W. (1968). Three new Pratylenchus species with a discussion of the structure of the cephalic framework and of spermatheca in this genus. Nematologica 14, 497-510.

SPIRIDONOV, S.E., HoMINICK, W.M. \& BRISCOE, B.R. (1999). Morphology of amoeboid cells in the uterus of Steinernema species (Rhabditida: Steinernematidae). Russian Journal of Nematology 7, 39-42.

SPIRIdonov, S.E., ReId, A.P., Podrucka, K., Subbotin, S.A. \& Moens, M. (2004). Phylogenetic relationships within the genus Steinernema (Nematoda: Rhabditida) as inferred from analyses of sequences of the ITSI-5.8S-ITS2 region of rDNA and morphological features. Nematology 6 , 547-566.

STOCK, S.P. \& REID, A.P. (2004). Biosystematics of entomopathogenic nematodes (Steinernematidae, Heterorhabditidae): current status and future directions. In: Cook, R. \& Hunt, D.J. (Eds). Proceedings of the Fourth International Congress of Nematology, 8-13 June 2002, Tenerife, Spain.
Nematology Monographs and Perspectives, vol. 2. Leiden, The Netherlands, Brill, pp. 435-446.

Stock, S.P., Campbell, J.F. \& Nadler, S.A. (2001). Phylogeny of Steinernema Travassos, 1927 (Cephalobina: Steinernematidae) inferred from ribosomal DNA sequences and morphological characters. Journal of Parasitology 87, 877-889.

Stock, S.P., Griffin, C.T. \& Chaerani, R. (2004). Morphological and molecular characterisation of Steinernema hermaphroditum $\mathrm{n}$. sp. (Nematoda: Steinernematidae), an entomopathogenic nematode from Indonesia, and its phylogenetic relationships with other members of the genus. Nematology 6, 401-412.

Strome, S. (1986). Fluorescence visualisation of the distribution of microfilaments in gonads and early embryos of the nematode Caenorhabditis elegans. Journal of Cell Biology 103, 2241-2252.

TURK, F. (1903). Über einige im Golfe von Neapel frei lebende Nematoden. Mitteilungen der Zoologischen Station zu Neapel 16, 281-348.

VAN DE VElde, M.C. \& Coomans, A. (1988). Electron microscopy of germ cells and the ovarian wall in Xiphinema (Nematoda). Tissue and Cell 20, 881-890.

Wada, T., McKee, M.D., Steitz, S. \& Giachelli, C.M. (1999). Calcification of vascular smooth muscle cell cultures: inhibition by osteopontin. Circulation Research 84, 166-178.

YUEN, P.H. (1971). Electron microscopic studies on Aphelenchoides blastophthorus (Nematoda). I. The female genital tube. Nematologica 17, 1-12.

YUSHIN, V.V. \& MALAKHOV, V.V. (1997). Ultrastructure of the female reproductive system of the free-living marine nematode Enoplus demani (Nematoda: Enoplida). Fundamental and Applied Nematology 20, 115-125. 